\title{
Teaching and learning about food and nutrition through science education in Brazilian schools: an intersection of knowledge
}

\author{
Ensinando e aprendendo sobre alimentação e nutrição através \\ da educação em ciências: uma interseção de conhecimentos
}

\author{
Carolina Netto Rangel ${ }^{1}$ \\ Rebecca Nunn ${ }^{1}$ \\ Fernanda Dysarz ${ }^{1}$ \\ Elizabete Silva ${ }^{1}$ \\ Alexandre Brasil Fonseca ${ }^{1}$
}

${ }^{1}$ Laboratório de Currículo e Ensino, Núcleo de Tecnologia Educacional para a Saúde, Universidade Federal do Rio de Janeiro. Av. Carlos Chagas Filho 373/Centro de Ciências da Saúde/Bloco A/Sala 12, Cidade Universitária. 21.949-902 Rio de Janeiro RJ Brasil.

rangelcnut@yahoo.com.br
Abstract Science teachers are the main professionals in schools who address health-related subjects, though food and nutrition education (FNE) projects are mainly planned by health professionals, especially nutritionists. The objective of this study is to create a transdisciplinary approximation between scientific research fields and practical fields from the analysis of an integrated case study conducted in Brazilian schools. In 2011, 10 days of observation were programmed in six schools in five cities. Semi-structured interviews were carried out with different social actors and data was analyzed using the complex thinking theory and the bricolage method of educational research. Planting of vegetable gardens or projects to improve table manners during mealtimes were identified in the schools. The results describe educational approaches used by science teachers to include FNE in school activities, even when not described in the official curriculum. Health professionals can identify actions to support health education in schools starting with that already undertaken by science teachers. The successful initiatives also involved professionals with practical knowledge and experience of life.

Key words Food and nutrition education, Health education, Science education, Transdisciplinarity
Resumo Professores de ciências são os principais profissionais nas escolas dedicados a temas de saúde, mas projetos de educação alimentar e nutricional (EAN) são planejados principalmente por profissionais de saúde, em especial, por nutricionistas. O objetivo deste estudo foi construir uma aproximação transdisciplinar entre campos de pesquisa científica e campos de prática, a partir da análise de um estudo de caso integrado realizado em escolas brasileiras. Em 2011, foram realizados 10 dias de observação em seis escolas de cinco cidades. Entrevistas semiestruturadas foram realizadas com diversos atores sociais e os dados analizados a partir da teoria do pensamento complexo e da metodologia da bricolagem em pesquisa. O cultivo de hortas, ou projetos que visavam a bons hábitos nas refeições, foram identificados nas escolas. Os resultados descrevem abordagens educativas utilizadas por professores de ciências para incluir EAN nas atividades escolares, mesmo quando não estão previstas no currículo formal. Profissionais de saúde podem identificar propostas de educação em saúde nas escolas que partam de atividades já realizadas por professores de ciências. As iniciativas bem sucedidas envolveram também profissionais com o conhecimento prático e a experiência de vida.

Palavras-chave Educação alimentar e nutricional, Educação em saúde, Educação em ciências, Transdisciplinaridade 


\section{Introduction}

Recently the debate surrounding healthy eating has come to the fore and stimulated a variety of initiatives across society, including in schools. This field of knowledge is usually discussed and theorised by health professionals in order to plan interventions to improve populations' health conditions. Nevertheless, when these interventions occur inside schools it becomes necessary to better understand teachers' usual approach towards the theme.

FNE in schools can be considered from several viewpoints within literature. As currently performed, health professionals plan FNE activities which are subsequently executed by teachers. Following execution, health professionals further research and analyze the results. From this literature we have brought together the key points that support the present paper's analysis, highlighting connections between food and eating at school, health education and science education.

Health professionals must be aware of current activities in schools to appropriately plan interventions and manage public policies. Several approaches to developing and evaluating teacher training for FNE were identified within the literature.

Some studies' approaches focus on promoting technical-scientific knowledge of food and nutrition among teachers, understanding that this enables them to enhance the school as an environment for health promotion ${ }^{1,2}$. Other recommendations broadening the focus from technical-scientific knowledge to public policy planning and action. Nevertheless, they define a space within the curriculum for FNE, not as a school subject, but as a transversal theme and in fact across school life as a whole ${ }^{3}$. Cooking activities form the centre of some approaches where different kinds of knowledge meet, allowing the development of technical-scientific knowledge alongside the exchange of popular knowledge and skills among different professional, age and gender groups. Focus is thus moved from curricular activities performed by the teacher to initiatives that promote the integration of several actors in developing the work ${ }^{4}$.

Therefore, we understand that teachers are key-actors inside the school context. They can contribute to construction of knowledge on this theme. This includes discussing concepts of healthy eating, developing methods to better understand their implications in the school context and in designing related initiatives.
The present study seeks to expand this discussion by building a transdisciplinary approach between fields of practice and scientific research, through analysis of an integrated case study in Brazilian schools.

\section{Building the transdisciplinarity of Food and Nutrition Education}

The presence of transdisciplinary views becomes fundamental particularly when scientific concepts are involved. Currently it is impossible to discuss health while disregarding scientific knowledge; conversely science education constitutes an important field to be considered in planning health education activities, especially in schools.

The content and knowledge involved in FNE go beyond the boundaries of a singular subject. The scientific knowledge within these themes combines several disciplines not necessarily linked directly to school subjects. The immersion of today's society into science, as a result of the development of scientific knowledge, has influenced the ways FNE can be established in schools.

Considering the concept of field ${ }^{5}$ we understand that scientific knowledge of food and nutrition (and its education) is constructed inside a social practice. In this, scientific social practice 'games of power' are played by researchers who hold credibility inside delimited fields. Each field of scientific knowledge defines: what is a scientific subject, what questions can be asked and how and by whom they can be answered. Thus, we consider it important to bring attention to the fields involved in the construction of science education and health education (Figure 1). In our understanding, educational approaches are not separated from the scientific knowledge constructed about them, and neither fields of knowledge nor educational practices can be separated from their political context.

In this context, to position FNE with these scientific disciplines could aid better understanding. This idea is demonstrated in Figure 1. Health is firstly formed with natural science knowledge, such as physics, chemistry and biology. With the passing of time, social sciences are recognised as scientific knowledge and assimilated into the field of health. Moreover, education appropriates knowledge from social sciences that already bring a strong influence from natural sciences due to their use of the scientific method.

The issue becomes more complex however as interactions continue. Health education and sci- 


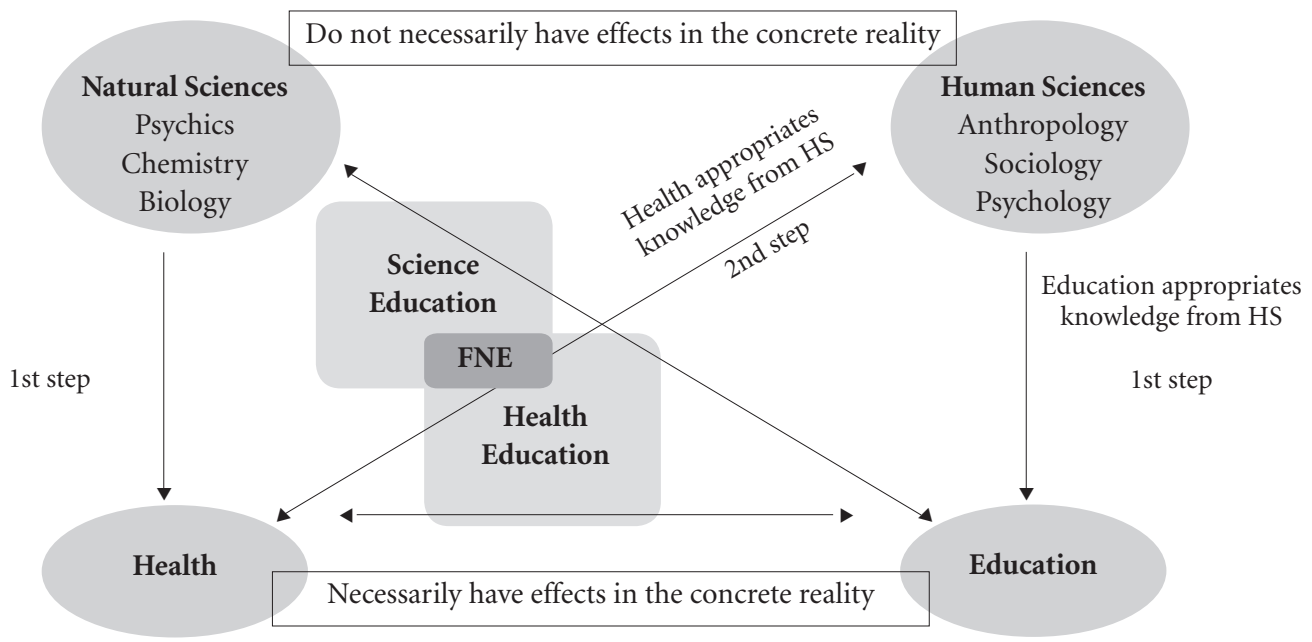

Figure 1. Food and nutrition education at the intersection of different fields of scientific knowledge.

ence education contain many aspects that converge with the aforementioned areas of knowledge and at their intersection we start to rethink FNE. In this context we understand education as a common element enabling us to move between health education, FNE and science education.

To solve the epistemological issue resulting from the intersection of several research fields we chose complex thinking in education,that suggests participation of an increased range of actors and joining perspectives on problems ${ }^{6}$. By broadening involvement in this way and accommodating these actors' ideals and objectives, thus reducing the need for assimilation and application of knowledge from different fields, we begin to build complex science.

Complex thinking involves simultaneities: events or phenomena that exist and occur at the same time. This presents a counterpoint to modern western thinking in terms of discontinuities: such separations as theory and practice, knowledge and knowers, I and others, body and mind, art and science, child and curriculum. Certainly complex thinking cannot answer all questions, but can help educators resolve dichotomous impasses such as yes/no, right/wrong, this/that ${ }^{6}$.

\section{Methodological procedures}

This study was planned based on the case studies methodology ${ }^{7}$, due to the possibility of using sev- eral investigative methods and comparing cases with the objective of understanding a multifaceted phenomenon.

The study's methodological design consisted of an integrated multiple case study in which each city represents a context and each school represents a case, in different parts of the country in order to investigate possible cultural differences. Using the Brazilian School Census ${ }^{8}$ the city within each region that reported the highest number of school FNE activities was selected, excluding those with fewer than 100,000 inhabitants. Where possible state capitals were avoided as they often monopolise the focus of national studies. However in the north and northeast only such capitals met the study criteria. The selected cities were: Vila Velha, Southeast; Aracaju, Northeast; Caxias do Sul, South; Aparecida de Goiânia, Midwest; and Macapá, North.

The Municipal Education Office of each selected city was contacted following research ethics committee approval. Each authorised the research and identified appropriate schools. In Vila Velha, the first city visited, the case study was performed in two schools. In each of the other four cities, one school was visited resulting in a total of six schools. Each school was visited in 2011 by a researcher who performed semi-structured direct observation, lasting approximately ten days. Furthermore, document analysis and formal, informal and group interviews were carried out with students, teachers, cooks, headmasters, PNAE nu- 
tritionists, researchers, politicians and members of the School Feeding Committee (CAE).

The integrated units of analysis were represented by different social actors within the schools. This paper's analysis focuses on the science teacher interviewed at each of the six schools. The semi-structured interviews were performed towards the end of the observation period. The interviews began with the question: "Please tell us how long you have been teaching and how you came to teach at this school?" After the initial question, it was possible to develop a better understanding of the interests of the teacher. Following this we asked about school activities related to food and nutrition, and whether they identified relationships between curriculum content and school meals. The questions were chosen during the conversation, to further investigate the most relevant points raised by the participant.

Direct observation records are also used to contextualise each experience. Non-participant observation was performed due to the short time available for research in each school and the need to investigate FNE in various spaces and activities. Observation was semi-structured to allow comparison between findings from different researchers and schools. The guiding question was "which aspects of school feeding, and educational activities on this topic, are observed in the schools?" These included physical aspects (e.g. building structure, images and furniture), routines, relationships between actors, conversations, body language and situations of particular interest that contrast with other schools or that school's standard routine. Observations were detailed using the interrogatives: what, who, where, when and how.

In order to analyze the data applying complex thinking theory ${ }^{9}$ we used the bricolage methodology of educational research ${ }^{10}$. The bricoleurs work through interdisciplinary limits looking for multiple perspectives, evaluating the quality of complex studies by the extent of their multidimensionality.

Each interview was transcribed and the main sub-units of analysis identified. The sub-units comprised convergent and complementary points from teachers' experiences. These were grouped in topics and comprehensive narratives to identify similarities and differences between interviews. Experiences lacking convergence with other teachers' points of view were not discarded, but used as individual observations in order to enrich the analysis.
Data collection and analysis were directed by key questions and propositions and counter-propositions. These questions were: "Which educational strategies of FNE are used in the schools? How do these strategies relate to the specific contexts of respective cities? Which observations add to the theoretical conceptualisation of school FNE?" The propositions were that the theoretical framework of school FNE is being developed through: 1) educational activities going beyond the formal curriculum are performed and 2) involvement of the whole school community, though particularly teachers. The counterpropositions were that: 1 ) only activities strictly related to the formal curriculum are undertaken with focus on content without stimulating critical thinking and 2) only teachers carry out these activities. Data was systematised according to theoretical replication to identify the proximity of the field observations to our initial propositions.

\section{Results}

When science teachers were asked about the relationship they see between their work and food and nutrition subjects, all of them described educational strategies they use to go beyond the formal curriculum. When we analyzed their interviews following systematisation, three main discussion topics were identified: kitchen and cooking, body health, and vegetable gardens.

\section{Mixing scientific and popular knowledge in the kitchen}

The teacher interviewed in Aracaju is degree qualified in nutrition education, an undergraduate course now discontinued. This teacher simultaneously fulfils the role of health professional and formal educator. While teaching science in secondary school he identified several possibilities to integrate health issues into the subject's curriculum. Specifically in the area of food and nutrition, he highlights the PNAE as a key element to be explored and used. He described a project he had proposed for implementation in school using the kitchen as a laboratory seeking to approach science themes while teaching the students culinary skills.

The teacher's focus on PNAE appears associated with his degree education. PNAE dieticians are not only responsible for the planning and execution of meals they also have an educational role. However they frequently adopt authoritar- 
ian attitudes towards knowledge in nutrition, judging it exclusive to dieticians. Thus they are usually against dialogue and, possibly unintentionally, often prioritise scientific over popular knowledge ${ }^{11}$. On the other hand, this teacher/ dietician understanding seems to be more integrating and directed at using cooking as an educational activity.

Other staff from this school also viewed school feeding as a potential educational environment. The curriculum coordinator or school principal supervised students at all meal times to guide behaviour and encourage the social potential of these times. In this context they were responsible for supporting the cooks and advising on students' food portions and preferences. Furthermore, they oversaw behaviour among students and between them and the cooks, specifically in the queues and to control noise in the dining hall. Teachers and coordinators, however, usually eat their meals independently from the children having a different mealtime and food prepared separately for them.

In Caxias do Sul the cook performed a similar function working alongside teachers and the school principal. Food was served to only 100 students divided by year and accompanied by their teachers. Due to this low number in the dining hall the cook was able to have a closer relationship with students knowing them all by name. Whilst serving food she talks to students and explains each component of the meal and how it was prepared. Teachers stayed in the dining hall during mealtimes, mainly supervising student behaviour. Thus the interaction between cooks, students and teachers created a learning atmosphere during school meals.

\section{Adding health to food}

In Caxias do Sul experiences related to industrialised foods, food's practicality and economic value, and the relationship between food consumption and chronic diseases. This was observed in a small, closely knit school where a student from the fifth year had been repeatedly hospitalised due to complications with diabetes and hyperlipidaemia. This experience, associated with his obesity, had a significant impact in the school. FNE activities thus focused on obesity and promoting healthy diets to control body weight. Additionally, the city health council's nutrition division had recently found $35 \%$ of its students to be obese or overweight demonstrating the need for interventions in schools. This re- inforced our understanding of the city context's influence upon the school and its activities.

Food and nutrition discussions remain focused upon the topic of obesity. Overweight and obesity among children and adolescents are growing concerns also observed in schools. Therefore, it was surprising this topic only emerged in one school in this study. It is possible the field of nutrition prioritises the issue more so than education, where other subjects receive greater importance.

\section{Cultivating vegetables, nature and experiences}

Vegetable gardens were the main point of convergence between interviews. They were emphasised as an educational tool in the cities of Vila Velha and Aparecida de Goiânia; in both cases coordinated by science teachers. In Macapá the teachers considered the school garden capable of many important contributions to FNE but faced difficulties maintaining it.

Most science education projects linked health to environmental issues by considering local wild fruit and their medicinal uses, food habits, hygiene, nutritional value and culturally specific foods. Through planting and maintaining vegetable gardens students were shown the origins of foods, different methods of food production and the association between plants and foods. Vegetable gardens were also used to demonstrate biological concepts involving plant growth and development. Furthermore, they were inclusive tools to bring awareness among students of each colleague's challenges and achievements and where students with special needs could develop physical skills.

In Vila Velha a project was being developed by a local institute for research and rural work promoting and creating community vegetable gardens for educational purposes. In schools these gardens were created to involve the community in its activities and occasionally supply food for its meals. The researcher responsible for the project highlighted the need for a community member to maintain the gardens. This is essential to the vegetable gardens' feasibility due to teachers viewing their maintenance as the main obstacle to their success.

In Aparecida de Goiânia the same issue was addressed by hiring two students' fathers who were experienced gardeners. Their salaries were financed from government funds for school activities (Programa Mais Educação) and revenue 
generated selling produce from the garden such as chillies and leaf vegetables.

The presence of a community member within the school can foster discussions around the value of rural work and the importance of knowledge gained through agricultural activities and experience. From a transdisciplinary perspective this aspect is fundamental because focus is brought upon rural workers' knowledge, and learning moves from being purely content oriented to an emphasis upon life and ways of living. Thus this community member becomes an educator, not to teach formal curricular content, but practical knowledge and lived experience.

In Vila Velha a vegetable garden was maintained by a primary teacher, her students and the cooks. This garden consisted of vegetables planted in a small part of the school's grounds that was frequented by students between lessons and was visible from the dining hall window. This area was previously used to store school equipment.

The project began with the cooks planting herbs and medicinal plants in this area, and subsequently the teacher developed it into a vegetable garden to teach science topics to students and allow them to use it. The students planted and maintained the garden during lessons and outside school times, experiences they valued. This project was feasible due to the garden's small area and the ease of growing herbs. Here the school cooks performed an educational role similar to the community members, sharing their knowledge and experience with students. The location of the garden, out of the kitchen's back door, created a friendly environment where the cooks interacted with the students while they prepared meals.

In Aparecida de Goiânia there was a different approach to vegetable gardens as educational tools because schools are located within a forest reserve. Saying here we have a big laboratory that is the forest itself the science teacher's proposal joined the vegetable garden and the forest creating an environment of integrated production. Focus was placed upon the educational significance of addressing environmental preservation and food production as connected and equally important themes. In his discourse, the teacher combined conservationist and critical viewpoints concerning the environment. The former was associated to the forest reserve, discussing the importance of the native forests and the relationship between human beings and this natural environment. Food production was discussed from a critical viewpoint involving social issues such as the widespread use of pesticides in Brazil.
The interview with the teacher from Macapá provided significant insight to the discussion of science teachers' role as the lead for environmental and healthy eating themes in schools. The teacher reported an unsuccessful experience with vegetable gardens in their school that he attributed to the lack of government interest and support. This contrasts with Vila Velha and Aparecida de Goiânia's initiatives which included governmental support for establishment and maintenance. However this should not be considered a determining factor since we observed most difficulties could be overcome through active involvement of teachers and other school staff.

In Macapá undergraduate students worked as instructors in the vegetable gardens as placements which are common structural elements of Brazilian degrees. They developed similar roles to Vila Velha's community members and Aparecida de Goiânia's fathers. However, the teacher in Macapá cited difficulties selecting these students as they need experience of both working with children and gardening:

Of course, the guilt isn't only of the [Municipal Education] Secretariat because we (teachers) were also involved, but many times you're limited in what you can do. [...] It starts with the Secretariat because the trainees were recommended by them, so they should make sure they are someone who at least has the ability to perform this work. [...] They have to work with children beyond working with the plot, so this person needs to know how to socialise their knowledge, but it didn't happen like this. (Macapá teacher).

In this context, once again, issues concerning practical knowledge, life experience and scientific and non-scientific knowledge acquired from working with different people groups recurred.

Interestingly this teacher majored in agricultural sciences, a degree which prepared professionals to teach in school the now obsolete subject agricultural techniques. With growing urbanisation and resulting political changes, agricultural techniques were gradually excluded from Brazilian curricula and these teachers were redirected to other school activities, including teaching science.

Despite his degree in this area, beyond the financial concerns, the teacher cited great difficulties in working with vegetable gardens due to changes in children's backgrounds. Previously, in what was a predominantly rural area, the teacher was responsible for adding theoretical, scientific knowledge to the practical knowledge students learnt at home. Now, educational work involving 
agricultural activities introduces students to a reality previously unknown to them, with the possibility of joining environmental, food and diet issues in the same activity.

This failure could be explained similarly to that observed by Silva and Fonseca ${ }^{12}$ where students and parents were resistant to agricultural activities. According to the teachers interviewed by these authors, students and parents expect the school to focus on intellectual studies involving theory and practice: on subjects such as technology and informatics. Additionally the cultural and social values associated with agriculture are not valued in today's society. Therefore practical activities that include soil, plants and nature in an urban environment were often rejected.

In successful cases, when gardens were first planted in schools, students were able to participate in the entire process: soil preparation, planting, maintenance and harvest. The food produced was used in school meals constituting an important link between educational work on the environment, food and eating issues, and between science and health education, with the PNAE as an essential partner.

The teacher from Macapá also emphasised the need for involvement of teachers from different subjects with the goal of integrating different knowledge areas in one activity. This transversal approach sometimes faced obstacles due to teachers' fragmented understanding of education as well as external demands such as national exams used to assess students' understanding of curriculum content.

\section{Discussion}

In general terms, data from the five case studies brought us to rethink the need for specialised knowledge and to understand that these themes can be presented in different areas of knowledge.

The main point of convergence was the use of school vegetable gardens as educational strategies to approach food and nutrition themes. We observed that science teachers frequently draw connections between food and the environment, viewing vegetable gardens as a way for students to experience these connections. Silva and Fonseca $^{12}$ also identified this trend and emphasised that currently in Brazil vegetable gardens are recommended for urban schools, nonetheless the physical structure and theoretical content for these activities is often unavailable. Voluntary initiatives are occurring aiming to provide environmental education and promote healthy eating habits. These initiatives usually rely on limited resources and are unsustainable. In simple terms they involve: planting, maintaining, harvesting, eating and maybe learning to make healthier food choices and to care for the environment. Material resources and technical, social and cultural aspects needed to establish and develop these projects are frequently ignored by managers within schools and on municipal and state levels. This leads to recurrent rejection and discontinuation of these projects.

Another important factor is the agroecological focus given by teachers when introducing vegetable gardens as educational tools. A fundamental contribution of agroecology to education is the horizontal relationship established between professionals encouraging the school to welcome popular knowledge from its surrounding community ${ }^{13}$. Through agroecology it is possible to create scientific and educational frameworks that meet the wide objectives of FNE and environmental education, supporting these activities in urban schools ${ }^{12}$.

Teachers are usually not trained in the area of nutrition, but are capable of developing educational activities that approach this theme with critical thinking, creating a link between food, eating, health, the environment and local development. Furthermore, the practical work performed by school staff, such as cooks and gardeners, adds experience essential to articulation of different areas of knowledge.

Planting can be understood as an action that connects human beings to nature and opens the opportunity for a "party of the five senses" 12 where there are possibilities to "smell, see, hear, touch and taste"14. We can refer in the same way to cooking. Thus as planting links to the environment, through culinary activities human beings are connected to their culture. Cooking is a cultural act. By shifting the focus from nutrition science to the experience of preparing food, their study presents technical-scientific knowledge as a result of practical experience and not the contrary ${ }^{4}$.

In these contexts the school feeding program created the possibility of integrating topics such as food, health, education and the environment through teaching and learning processes around food production and preparation. This is one of the facets of the interaction between FNE and environmental education we identified in schools. It seems science teachers work as catalysts, fostering and managing transdisciplinary educational processes. 
These experiences show several similarities between community members who tend the vegetable gardens and the school cooks. The community members share practical knowledge on cultivating the garden's plants within the school environment while the cooks share practical knowledge on food preparation. Both can perform a role as informal educator providing they work closely with students and students recognise that this work contributes to their education. Thus when working alongside the teachers, community members and school cooks can contribute to widen the fields of knowledge beyond textbook content, the teachers being responsible for linking practical knowledge with curriculum content. Above this, the condition of the school cookers needs to be improved about conceptions, values and structural conditions, in order to concretize them as educational actors ${ }^{15}$.

Conversely, to accept traditional understandings of food and eating without criticism, and ignoring environmental and life style changes throughout the years could also be a great mistake. If teaching scientific principles (inside and outside of school) is truly a health promotion strategy then important aspects of science education must be considered.

Cobern \& Loving ${ }^{16}$ support the idea of epistemological pluralism in which the most adequate perspective may be adopted in different circumstances and statements. Thus a scientific explanation can be used to answer a question alongside knowledge from other areas such as philosophy, economics, history, politics, religion, and traditional knowledge among others. Thus the area of knowledge most appropriate to the situation is applied, sometimes scientific others not. Hence, with a broad understanding of transdisciplinarity, we can advance in seeking to integrate the areas of scientific knowledge found at the intersection of these fields with non-scientific knowledge.

What must be kept in mind when teaching science is not its assumed capacity to reveal and explain the truth, but its ability to develop an understanding of when this area of knowledge is the most useful. To know the limitations and recognise the specificities of scientific knowledge contributes to the understanding of when it may be useful and when it is being inappropriately stretched into other areas of knowledge ${ }^{16}$. This comprehension of science and teaching goes beyond the traditional transmission of concepts, which is sometimes reproduced in research and activities involving FNE.
In these cases, we observed that non-scientific knowledge is introduced through practical activities and experience brought by a few school staff members recognised as informal educators. In the PNAE, cooks specifically have this role while in the vegetable gardens different members of the community can be involved.

When comparing this study's theoretical considerations and empirical observations we are able to add aspects to Figure 1. Beyond interactions of theory, methodology and professional profiles between scientific fields, it is possible to include knowledge outside the boundaries of science. This knowledge is represented by cultural aspects, shared life experience and gained practical knowledge (Figure 2). Understanding, complexity in education requires more accommodation and participation instead of assimilation and application. Simultaneities, characteristic of complex thinking, occur when knowledge is created through actors participation joining diverse experiences and knowledge that combined can result in something effectively new ${ }^{6}$.

We must also consider that each professional's goals and methods differ to others, thus working together is often complicated. Accommodation takes place when several participants are inclined to question their own knowledge and renegotiate the objectives of a common activity. For example, dieticians are primarily concerned with ensuring health whilst teachers focus on other aspects such as the development of specific abilities and citizenship. In the same way, school cooks are responsible for preparing meals, gardeners for maintaining the vegetable gardens and the students for achieving what is required for schooling qualification. These objectives are not isolated but interact in complex ways within which transdisciplinarity occurs.

\section{Final considerations, conclusions and perspectives}

Some teachers appoint the pedagogical potential of the PNAE to connect health, environmental, local development and science topics. However, due to the need to follow curriculum content, this potential is little explored in schools. We conclude that making teachers exclusively responsible for these educational activities is usually ineffective. In the studied cases successful initiatives involved additional professionals who carried out complementary roles. They function not as teachers' assistants, but as informal educa- 


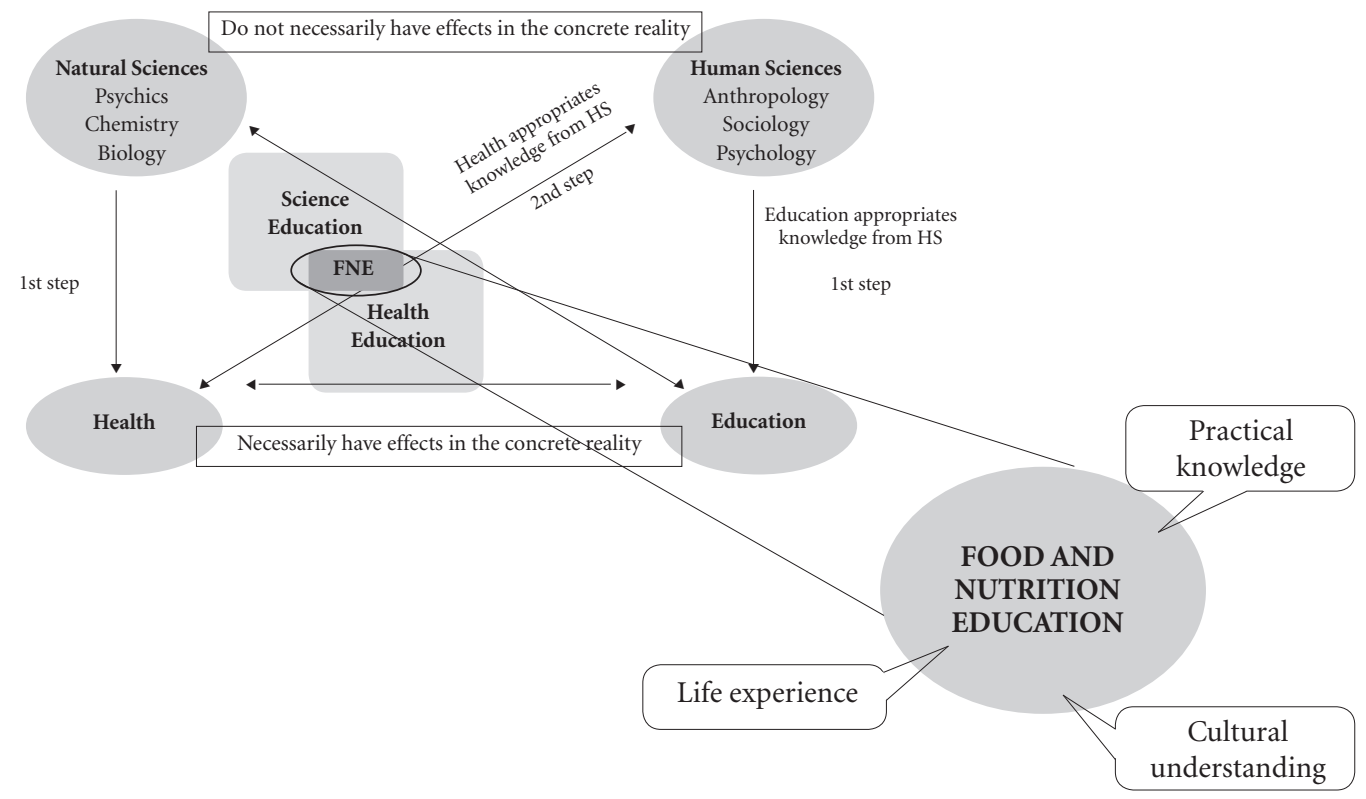

Figure 2. Non-scientific knowledge involved with food and nutrition education.

tors representing an important link between the curriculum subjects and practical knowledge and experience.

We identified that the main point of tension in transdisciplinary interactions between science, education, health and environment is not related to abstract knowledge itself, but to the relationship between professionals in their work whether scientific or not. In the case studies this was avoided this when science teachers valued vegetable garden or culinary activities, including theoretical content from the formal curriculum as well as life experience, practical knowledge and cultural aspects. We thus find that technical-scientific and cultural/practical knowledge were brought together through inclusion of the school community (parents, staff and students) in formal activities planned by teachers. By understanding FNE as a field of social practices in which scientific knowledge is built, the actors that participate are of greater significance than the knowledge itself. If knowledge is created within social practices then the question 'who creates?' becomes critical.

According to the teachers' perceptions, through their school activities they perform
FNE. Dieticians do not always share this perception and often plan interventions in schools without considering those being implemented by teachers. We observed that activities developed by teachers were in fact FNE. Thus we consider that teachers are able to contribute to the theoretical framework of FNE in schools not solely by executing activities previously planned by health professionals.

Health and education professionals and other actors involved in school activities should define objectives, discuss presuppositions and elaborate strategies together. Interactions between them can improve the quality of school FNE theories and practice whilst shifting the schools role from merely executing PNAE to enabling the creation of new knowledge.

The development of activities with strong connections to everyday life, such as those related to eating, with an approach that establishes a hierarchy of knowledge has often proved fruitless. Horizontal relationships between actors and knowledge can better value health issues associated to food and nutrition. We conclude that when speaking of planting and cooking, less is said of illness and death. 


\section{Collaborations}

CN Rangel, R Greenwood and AB Fonseca idealized, carried out, analyzed and wrote this paper. E Silva and F Dysarz contribute with the critical discussion and written of paper.

\section{Acknowledgements}

The authors would like to acknowledge the Observatório da Educação-CAPES/INEP/CNPq for financial support and the Municipal Education Offices who authorised the research inside the schools.

\section{References}

1. Davanço GM, Taddei J AAC, Gaglianone CP. Conhecimentos, atitudes e práticas de professores de ciclo básico, expostos e não expostos a Curso de Educação Nutricional. Braz J Nutr. 2004; 17(2):177-184.

2. Schmitz BAS, Recine E, Cardoso GT, Silva JRM, Amorim NFA, Bernardon R, Rodrigues MLCF. A escola promovendo hábitos alimentares saudáveis: uma proposta metodológica de capacitação para educadores e donos de cantina escolar. Cad Saude Publica 2008; 24(2):312322.

3. Bizzo MLG, Leder L. Educação nutricional nos parâmetros curriculares nacionais para o ensino fundamental. Braz J Nutr 2005; 18(5):661-667.

4. Castro IRR, Souza TSN, Maldonado LA, Caniné ES, Rotenberg S, Gugelmin SA. A culinária na promoção da alimentação saudável: delineamento e experimentação de método educativo dirigido a adolescentes e a profissionais das redes de saúde e de educação. Braz J Nutr 2007; 20(6):571-588.

5. Ortiz R, organizador. Bourdieu - Sociologia. São Paulo: Ática; 1983.

6. Davis B. Complexity and Education: Vital simultaneities. Ed Philosophy and Theory 2008; 40(1):50-65.

7. Yin RK. Estudo de caso: planejamento e métodos. $4^{\mathrm{a}}$ ed. Porto Alegre: Bookman; 2010.

8. Instituto Nacional de Estatística e Pesquisa (INEP). Avaliação do Programa Nacional de Alimentação Escolar (PNAE) - Censo Escolar 2004. Brasília: MEC; 2007.

9. Morin E. A religação dos saberes: o desafio do século. Rio de Janeiro: Bertrand Brasil; 2010.
10. Kincheloe JL, Berry KS. Pesquisa em educação: conceituando a bricolagem. Porto Alegre: Artmed; 2005.

11. Caniné E, Ribeiro V. A prática do nutricionista em escolas municipais do Rio de Janeiro: um espaço-tempo educativo. Ciência \& Educação 2007; 13(1):47-70.

12. Silva ECR, Fonseca ABF. Hortas em escolas urbanas, Complexidade e transdisciplinaridade: Contribuições para a Educação Ambiental e para a Educação em Saúde. Rev Bras Pesq Ed em Ciências 2011; 11(3):35-53.

13. Sevilla Gusmán E. A perspectiva sociológica em Agroecologia: uma sistematização de seus métodos e técnicas. Rev Agroecologia e Desenvolvimento Rural Sustentável 2002; 3(1):18-28.

14. Alves R. O quarto do mistério. Campinas: Papirus; 1995.

15. Fernandes AGS, Fonseca AB, Silva AA. Alimentação escolar como espaço para educação em saúde: percepção das merendeiras do município do Rio de Janeiro. Cien Saude Colet 2014; 19(1):37-46.

16. Cobern WW, Loving CC. Defining "Science" in a Multicultural World: implications for Science Education. Hoboken: John Wiley \& Sons; 2000.

Artigo apresentado em 25/07/2013

Aprovado em 17/09/2013

Versão final apresentada em 21/09/2013 